\title{
Decrease in litter weight gain and in progesterone secretion in lactating rats treated with antiserum to rat prolactin
}

\author{
H. Tomogane, K. Ôta and A. Yokoyama \\ Faculty of Agriculture, Nagoya University, Nagoya, 464, Japan
}

In a previous paper (Tomogane, Ôta \& Yokoyama, 1975), we demonstrated that prolactin was an important factor for stimulating the secretion of progesterone in lactating rats by using ergocornine, a specific inhibitor of prolactin secretion. In the present paper, preliminary results (Tomogane et al., 1973) have been extended by neutralizing circulating prolactin with an antiserum to rat prolactin (anti-RPL).

\section{Methods}

Primiparous Wistar-Imamichi rats (250-300 g) were used. They were kept in a temperature$\left(24 \pm 2^{\circ} \mathrm{C}\right)$ and light- (14 hr light: $10 \mathrm{hr}$ dark, lights on 05.00 hours) controlled room, and given free access to a commercial diet (CA-1, Nihon CLEA Ltd, Tokyo) and water. The day on which young were found between 09.00 and 12.00 hours was designated as Day 0 of lactation. Within 2 days of parturition the litter size was adjusted to 8,4 of each sex being kept whenever possible. Body weight and food consumption of the mother, and the gain in litter weight were recorded every morning (08.30-09.30 hours). Vaginal smears of the mothers were taken at the same time. The daily gain in litter weight was measured because it has been established that prolactin is indispensable for maintaining lactation in the rat (see Cowie \& Tindal, 1971, for review).

In Exp. I, animals were injected i.p. with either $1 \mathrm{ml}$ anti-RPL or $1 \mathrm{ml}$ normal rabbit serum (NRS) at 09.00 and 17.00 hours on Day 10 of lactation, and the litter gain and period of lactational dioestrus were recorded.

In Exp. II, progestins in the ovarian vein blood were measured. Animals were allocated to 3 groups and were injected i.p. at 09.00 and $\mathbf{1 7 . 0 0}$ hours on Day 10 of lactation with $1 \mathrm{ml}$ anti-RPL, $1 \mathrm{ml}$ anti-RPL $+1.0 \mathrm{mg}$ bovine prolactin (NIH-P-B-3, 24 i.u. $/ \mathrm{mg}$ in $0.5 \mathrm{ml} \mathrm{0.9 \%}(\mathrm{w} / \mathrm{v}) \mathrm{NaCl}$ ), or $1 \mathrm{ml}$ NRS. Bovine prolactin was used for the replacement, since there is no cross-reaction between bovine prolactin and anti-RPL (Ellis, Grindeland, Nuenke \& Callahan, 1969). At 09.00 hours on Day 11, the animals of each group were anaesthetized with sodium pentobarbitone $(35 \mathrm{mg} / \mathrm{kg}$, i.p., Nembutal, Abbott) and injected with $0.5 \mathrm{ml}$ anti-RPL, $0.5 \mathrm{ml}$ anti-RPL $+1.0 \mathrm{mg}$ bovine prolactin and $1 \mathrm{ml} \mathrm{NRS,} \mathrm{respectively,} \mathrm{into} \mathrm{the} \mathrm{jugular} \mathrm{vein.} \mathrm{Blood} \mathrm{was} \mathrm{collected} \mathrm{from} \mathrm{the} \mathrm{ovarian}$ vein, starting $1 \mathrm{hr}$ after the serum injection and continuing for 1-1.5 hr. The animals were then killed and the anterior pituitary gland, ovaries and uteri were removed and weighed. Extraction, separation and measurement of progestins were performed by the method of Tomogane $e t$ al. (1975). The gain in litter weight in the rats treated with anti-RPL + bovine prolactin was measured on Days 10 and 11.

The antiserum to rat prolactin was prepared in a female rabbit $(3.5 \mathrm{~kg})$ of the Japanese White strain. The animal was injected s.c. three times at intervals of about 10 days with $3 \mathrm{mg}$ rat prolactin (NIAMD-PL-RP1) in $3 \mathrm{ml} 0.9 \%(\mathrm{w} / \mathrm{v}) \mathrm{NaCl}$ emulsified with an equal volume of Freund's complete adjuvant. A booster injection of $0.8 \mathrm{mg}$ prolactin in $0.8 \mathrm{ml} 0.9 \% \mathrm{NaCl}$ was given via an ear vein 46 days after the first injection. Whole blood was collected 2 weeks later. The serum was separated and stored in a deep freeze until required. The titre of the anti-RPL thus obtained was 1:64 against the rat prolactin $(1 \mathrm{mg} / \mathrm{ml} \mathrm{0.9 \%} \mathrm{NaCl})$.

Duncan's multiple range test, as modified by Kramer (1956), and Student's $t$ test were used for the statistical analysis. 


\section{Results and discussion}

A suppressing effect of anti-RPL on lactation appeared very quickly. On Day 11 , the daily gain in litter weight of the anti-RPL-treated animals was significantly reduced from that on Day 10(Table 1). The gain returned to the pretreatment level on the following day. No appreciable decrease in the daily gain was observed in NRS-treated rats on Day 11 of lactation. Injection of bovine prolactin simultaneously with anti-RPL prevented the decrease and restored the litter weight gain. The difference in the gain on Days 10 and 11 was not significant at the $5 \%$ level. The decrease in milk production observed could not be ascribed to the effect of the treatments on the food intake of the mother (Table 1). These results indicate that anti-RPL used in the present study could neutralize endogenous prolactin and that bovine prolactin was to some extent able to take the place of endogenous rat prolactin, thus confirming that prolactin is indispensable for maintaining lactation in rats (see Cowie \& Tindal, 1971, for review).

Table 1. The effect of treatment of lactating rats with antiserum to rat prolactin (mean \pm S.E.M., no. of rats in parentheses)

\begin{tabular}{|c|c|c|c|}
\hline Day of lactation & NRS & Anti-RPL & $\begin{array}{c}\text { Anti-RPL } \\
+ \\
\text { bovine prolactin }\end{array}$ \\
\hline \multicolumn{4}{|l|}{ Gain in litter weight (g/day) } \\
\hline 10 & $14 \cdot 6 \pm 2 \cdot 2(5)$ & $17 \cdot 1 \pm 1 \cdot 6(4)$ & $* 12 \cdot 9 \pm 1 \cdot 2(6)$ \\
\hline 11 & $13 \cdot 2 \pm 1 \cdot 8(5)^{\mathrm{a}}$ & $3 \cdot 1 \pm 2 \cdot 4(4)^{b}$ & ${ }^{*} 8.9 \pm 1.4(6)^{a}$ \\
\hline 12 & $12 \cdot 0 \pm 1 \cdot 3(5)$ & $8 \cdot 9 \pm 1.4(4)$ & - \\
\hline \multicolumn{4}{|l|}{ Food intake of mother (g/day) } \\
\hline 10 & $42 \cdot 7 \pm 2 \cdot 0(5)$ & $38 \cdot 8 \pm 5 \cdot 5(4)$ & $* 39 \cdot 2 \pm 1 \cdot 6(6)$ \\
\hline 11 & $39 \cdot 1 \pm 3 \cdot 0(5)^{\mathrm{c}}$ & $29.6 \pm 3.5(4)^{d}$ & $* 33 \cdot 7 \pm 3 \cdot 2(6)^{e}$ \\
\hline 12 & $44 \cdot 0 \pm 3 \cdot 5(5)$ & $42 \cdot 4 \pm 3 \cdot 2(4)$ & - \\
\hline \multicolumn{4}{|l|}{ Progestin concentration $(\mu \mathrm{g} / 100 \mathrm{ml})$} \\
\hline Progesterone & $160 \cdot 7 \pm 32 \cdot 0(5)^{\mathrm{f}}$ & $66 \cdot 5 \pm 25 \cdot 0(6)^{\mathrm{z}}$ & $287 \cdot 4 \pm 63 \cdot 7(6)^{\mathrm{h}}$ \\
\hline 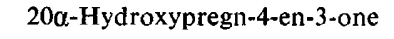 & $38 \cdot 5 \pm 14 \cdot 5(5)^{i}$ & $55 \cdot 3 \pm 16.9(6)^{i}$ & $55 \cdot 3 \pm 11 \cdot 3(6)^{i}$ \\
\hline
\end{tabular}

Sinha, Lewis \& Vanderlaan (1972), using lactating mice, reported that the effect of antiserum to mouse prolactin on the gain in litter weight appeared slowly. This difference between the two species might be due to variations in the titre of the antiserum used or to the method of administration. It is also possible that prolactin might be a more important hormone for the maintenance of lactation in the rat than in the mouse.

The concentration of $20 \alpha$-hydroxypregn-4-en-3-one was unaffected but that of progesterone in the ovarian venous blood of the rats treated with anti-RPL was significantly $(P<0.05)$ decreased to $40 \%$ of that present in the NRS-treated animals (Table 1 ). The small amount of progesterone still secreted after the anti-RPL treatment might be due to the stimulatory action of LH on the corpus luteum, since several workers (Yoshinaga, 1974; Rothchild, Pepe \& Morishige, 1974; Ford \& Yoshinaga, 1975) have suggested that LH and prolactin together constitute a luteotrophic hormone complex in the rat. We have demonstrated, however, that ergocornine treatment depressed progesterone to an undetectable level (Tomogane $e t$ al., 1975), and it is possible that the titre of antiserum in the present experiment was too low to neutralize completely the circulating prolactin. The fact that the decrease in the gain in litter weight obtained in the present experiment was much less than that observed in the rats treated with ergocornine supports this possibility. Moreover, there was no interruption of the lactational dioestrus in the present study: the lactational dioestrous period was $22 \cdot 3 \pm 0.5$ days (Mean \pm S.E.M.) in animals treated with anti-RPL and $22.7 \pm 0.4$ days (Mean \pm S.E.M.) in NRS-treated animals. This also differed from the previous results of ergocornine treat- 
ment and may be attributed to the small amount of progesterone secreted after the anti-RPL treatment.

Unlike the effect on litter weight gain, the concentration of progesterone in the rats treated with anti-RPL + bovine prolactin was significantly $(P<0.01)$ higher than in the other rats, suggesting that biological activity of the homologous prolactin may differ from that of the heterologous prolactin. The possibility remains, however, that the dosage of prolactin required for maintenance of milk secretion may not be the same as that required for luteal function.

After completion of these experiments, results of a similar nature were reported by Shani, Goldhaber \& Sulman (1975) who demonstrated a decrease in milk yield in rats treated with rabbit anti-rat prolactin serum from Days 2 to 20 of lactation.

We thank the NIAMDD for the bovine and rat prolactin preparations; Dr A. T. Cowie for reading the manuscript; and Mr R. Ogawa and Mrs Y. Niwa for assistance.

\section{References}

Cowie, A.T. \& TINDal, J.S. (1971) The Physiology of Lactation. Edward Arnold, London.

Ellis, S., Grindeland, R.E., Nuenke, J.M. \& CallaHAN, P.X. (1969) Purification and properties of rat prolactin. Endocrinology 85, 886-894.

Ford, J.J. \& YoshinaGa, K. (1975) The role of LH in the luteotrophic process of lactating rats. Endocrinology 96, 329-334.

Kramer, C.Y. (1956) Extension of multiple range tests to group means with unequal numbers of replications. Biometrics 12, 307-310.

Rothchild, I., Pepe, G.J. \& Morishige, W.K. (1974) Factors affecting the dependency on $\mathrm{LH}$ in the regulation of corpus luteum progesterone secretion in the rat. Endocrinology 95, 280-288.

Shani (Mishkinsky), J., Goldhaber, G. \& Sulman, F.G. (1975) Effect of antiserum to rat prolactin on milk yield and food intake in the rat. J. Reprod. Fert. 43, 571-573.
Sinha, Y.N., Lewis, U.J. \& VANDERlaAN, W.P. (1972) Effects of administering antisera to mouse growth hormone and prolactin on gain in litter weight and on mammary nucleic acid content of lactating C3H mice. J. Endocr. 55, 31-40.

Tomogane, H., Ôta, K. \& Yokoyama, A. (1973) [Changes in litter weight gain, prolactin contents of the pituitary gland and in progestin levels in the ovarian vein blood in lactating rats treated with anti-rat prolactin serum.] Jap. J. Zootech. Sci. 44, Suppl. II, p. 42, Abstr. In Japanese.

Tomogane, H., Ôta, K. \& Yokoyama, A. (1975) Suppression of progesterone secretion in lactating rats by administration of ergocornine and the effect of prolactin replacement. $J$. Endocr. 65, 155-161.

YoshinaGA, K. (1974) Ovarian progestin secretion in lactating rats: effect of intrabursal injection of prolactin antiserum, prolactin and LH. Endocrinology 94, 829-834. 